\title{
Spectrophotometric and High Performance Liquid Chromatographic Methods for the Determination of Dapsone in a Pharmaceutical Preparation
}

\author{
Lamya A. Sarsam \\ Department of Chemistry \\ College of Science \\ University of Mosul \\ E-mail: luma_sarsam@yahoo.com
}

(Received 5/6/2012;Accepted 18/7/2012 )

\begin{abstract}
The detailed investigation of a sensitive and selective spectrophotometric method for the determination of dapsone; based on the oxidative coupling reaction of dapsone drug with pyrocatechol in the presence of potassium periodate in acidic medium to form an intense, stable, purple-red coloured water-soluble dye, which shows a maximum absorption at $509 \mathrm{~nm}$. Beer's law obeyed over the range of 10-500 $\mu \mathrm{g} / 25 \mathrm{ml}$, i.e, $0.4-20 \mathrm{ppm}$ with a molar absorptivity of $1.05 \times 10^{4} 1 . \mathrm{mol}^{-1} . \mathrm{cm}^{-1}$ and Sandell's sensitivity index of $0.0235 \mu \mathrm{g} . \mathrm{cm}^{-}$ ${ }^{2}$,a relative standard deviation of \pm 2.60 to $\pm 1.05 \%$; and limit of detection, (LOD) of 0.1735 $\mu \mathrm{g} . \mathrm{ml}^{-1}$.; and (LOQ) of $0.5785 \mu \mathrm{g} \cdot \mathrm{ml}^{-1}$. And the method does not require temperature control or solvent extraction. HPLC technique has been also developed for the measurement of dapsone. The analysis was achieved on a $\mathrm{C}_{18}$ column using water and acetonitrile in the ratio of $50: 50(\mathrm{~V}: \mathrm{V})$ as a mobile phase at a flow rate equals to $0.5 \mathrm{ml} / \mathrm{min}$. and the detection was done spectrophotometrically at $297 \mathrm{~nm}$. A linear relationship is obeyed over the range $0.5-20 \mathrm{ppm}$ with a relative standard deviation (RSD) \pm 1.53 to $\pm 0.83 \%$ and relative error -0.3 to $+1.1 \%$. Both methods were applied successfully to the assay of dapsone in pharmaceutical preparation (Tablet).
\end{abstract}

Keywords: Spectrophotometricy, high performance liquid chromatography, dapsone, pyrocatechol, reagent.

\section{القدير اللمي والكروماتوغرالي الملل عالي الاداء لقدير الدالبهن في طنحضر دوائي}

\section{الملغص}

يتضمن البهث طريقةطفية هسلسة والتقائية لقدير الدلبسون والتي تعتمد على مفاعلة الدلبسون مع

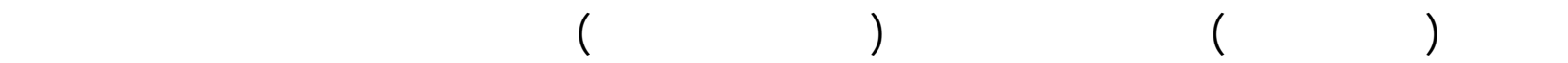
وذائبة في الماء ذات لون وردي - محمر وتطي اعلى لمتصاص عند الطول الموجي 509 نانوميتر، وكانت

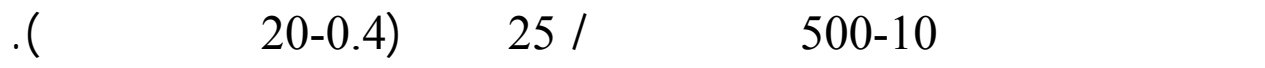




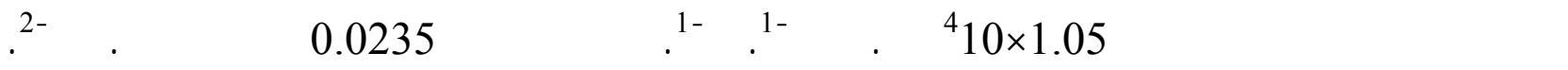

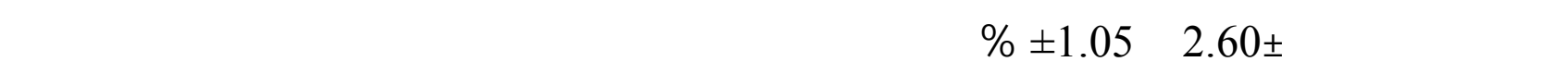

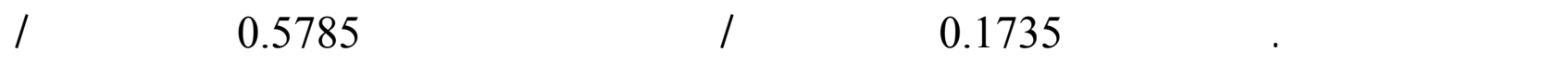

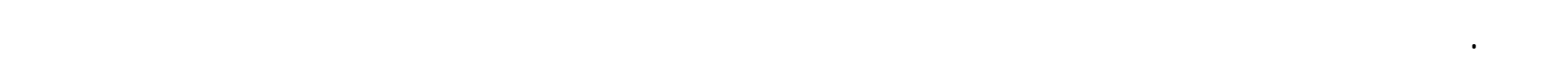

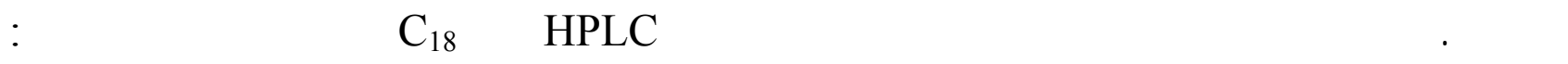

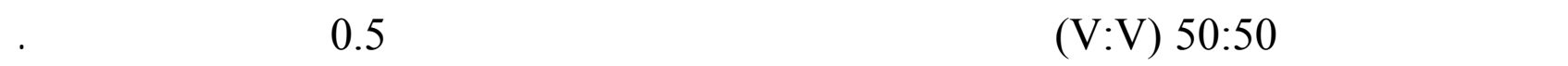

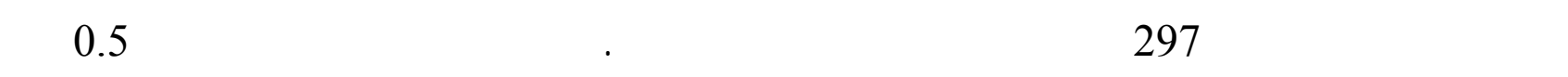

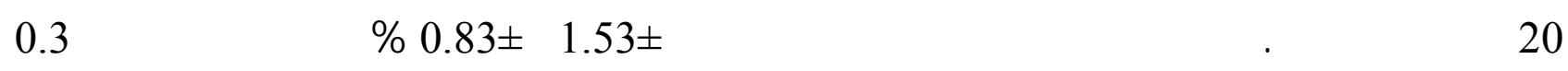
- و.1.1\%. وقد م قطبق كلا الطريقتن وبنجاح لقدير الدلبسون في الاقراص الدوائية.

الكاملت الدالة:طف الامتصاص، كروماتوغرافي للسالل عالي الأداء، الدلبسون، البايروكاتيكول.

\section{INTRODUCTION}

Dapsone (diamino-diphenyl sulfone, DDS), is a white or slightly yellowish-white crystalline powder. It discolours on exposure to light but this is not accompanied by a significant decomposition (Moffat et al., 2005). Dapsone is widely employed as effective antibiotic for prophyl axis agent pneumocystis carinii pneumonia and an opportunistic disease in (HIV) infection. It's approved as antibiotic by food and drug adminstration since 1963. (Saillourglenisson et al., 2000). Dapsone is a medication most commonly used in combination with rifampicin and clofazimine as multidrug therapy (MDT) for the treatment of mycobacterium leprae infections (Leprosy), and with pyrimethamine in the treatment of malaria (Croft, 2007 ; Alkadi, 2007).

Among the various methods available for the estimation of dapsone are electrophoresis, gas chromatography and HPLC. Spectrophotometry is still a preferred technique due to its simplicity. Several spectrophotometric methods are available for the estimation of dapsone using diazotization and coupling with $\alpha$-naphthol in the presence of sodium carbonate (Mohammed, 1994), dibenzoylmethane in an alkaline medium (Revanasiddappa and Manju, 2001), N-(1-naphthyl)ethylenediamine dihydrochloride (N-NED) in a hydrochloric acid medium (Nagaraja et al., 2001), iminodibenzyl in alcohol medium (Nagaraja et al., 2002), 3-aminophenol in aqueous medium (Nagaraja et al., 2003), sodium 1,2-naphthaquinone-4sulfonic as the chromogenic reagent (Wang et al., 2004), benzoylacetone in alkaline medium (Omran, 2005), $\alpha$-naphthol in strong alkaline medium in the presence of cetavlon (Al-Ramadani, 2007), phloroglucinol in basic medium (Daood, 2008).

Charge-transfer reactions are used for the determination of dapsone using different reagents such as chloranil (Mahmood, 2000), flouranil (Al-Gabsha et al., 2004), 2,3dichloro-5,6-dicyano-benzoquinon (DDQ) (Al-Gabsha et al., 2004).

Other methods used oxidative coupling reaction with different reagents such as: promethazine in the presence of hypochlorite as oxidizing agent (Al-Abachi et al., 1995), 4amino-N,N-diethylaniline in the presence of dichromate in acidic medium (Al-Abachi, 
1997) by using the same method (Al- Talib,1997) replaced the reagent with 4-amino-N,Ndimethylaniline, and N,N-diethyl-p-phenylendiamine sulphate in the presence of $\mathrm{KIO}_{4}$ was used (Nagaraja et al., 2010).

Liquid chromatography has been used for the determination of dapsone in human plasma (Shirazi et al., 2001), in meat and milk (Hadjigeorgiou et al., 2009).

Other chromatographic methods have been used for the determination of dapsone in human plasma using HPLC technique (Queiroz et al., 1997), and HPLC with ultraviolet (Kwaddijk and Torano, 2002) and high-speed gradient liquid chromatography in serum (Luan Chen et al., 2003). Finally, the potentiation of dapsone induced methemoglobinemia by $\mathrm{N}$-acetyl cysteine in rats (Moraes et al., 2008).

This paper describes simple and sensitive method. The first method included spectrophotometric determination of dapsone via oxidative coupling reaction with pyrocatechol in presence of potassium periodate in acidic medium. The second method included the developed HPLC method, by using $\mathrm{C}_{18}$ column with water: acetonitrile (50:50) as a mobile phase. The methods have been applied successfully to the determination of dapsone in pharmaceutical preparation (Tablet).

\section{EXPERIMENTAL}

\section{Apparatus}

Spectral and absorbance measurements are carried out using Shimadzu UV-Visible Recording Spectrophotometer UV-160, with 1-cm plastic cells. The $\mathrm{pH}$ measurements were carried out using HANNA Instrument 211 microprocess $\mathrm{pH}$ meter.

A Shimadzu LC-20 AD HPLC system with C18 stainless steel column $(250 \mathrm{~mm} \times 4.6$ $\mathrm{mm}$ ) have been used in the analysis. Pump pressure 4.5-5.1 MPa and $20 \mu \mathrm{L}$ is injected. The mobile phase consisted of (50:50 V:V) water: acetonitrile. Ambient temperature, flow rate $(0.5 \mathrm{ml} / \mathrm{min}$.) and detector wavelength $(297 \mathrm{~nm})$.

\section{Reagents}

All chemicals used are of the pure analytical grade. Chemicals for HPLC are of analytical HPLC grades. Water used is double distilled and filtered using membrane filter.

\section{Extraction of dapsone from tablets (British Pharmacopoeia, 2009).}

10 tablets of dapsone were grinded and dissolved in acetone, the precipitate of dapsone was recrystalized (Ferry et al., 1964) twice to yield a pure dapsone of $178{ }^{\circ} \mathrm{C}$ as a melting point $\left(175-181^{\circ} \mathrm{C}\right)$.

\section{Dapsone solution, $100 \mu \mathrm{g} / \mathrm{ml}$.}

This solution was prepared by dissolving $0.01 \mathrm{~g}$ of recrystallized dapsone mentioned above in $3 \mathrm{ml}$ of ethanol and completed the volume to $100 \mathrm{ml}$ with distilled water in a volumetric flask then the solution was kept in a brown bottle.

\section{Pyrocatechol reagent solution.}

Pyrocatechol reagent solution $\left(2.7 \times 10^{-3} \mathrm{M}\right)$ was prepared by dissolving $0.03 \mathrm{~g}$ of pyrocatechol (Fluka) in distilled water and the solution is diluted to $100 \mathrm{ml}$ in a volumetric flask. The solution was transferred to a brown bottle and remained stable for only $24 \mathrm{hr}$. 
Potassium periodate solution $\mathrm{KIO}_{4}, 0.1 \%$.

This solution was prepared by dissolving $0.1 \mathrm{~g}$ of potassium periodate (Fluka) in 100 $\mathrm{ml}$ of distilled water in a calibrated flask. The solution is kept in a brown bottle and was stable for at least one week.

\section{Hydrochloric acid solution, $0.1 \mathrm{M}$.}

This solution was prepared by diluting $10 \mathrm{ml}$ of $1 \mathrm{M}$ hydrochloric acid to a $100 \mathrm{ml}$ with distilled water in a calibrated flask.

\section{Recommended procedure and calibration graph}

Aliquots of dapsone solution were placed into $25-\mathrm{ml}$ calibrated flasks so that their final amounts concentrations were between 10 to $500 \mu \mathrm{g}$. To each dapsone solution, $1.5 \mathrm{ml}$ of $2.7 \times 10^{-3} \mathrm{M}$ pyrocatechol reagent solution, $2 \mathrm{ml}$ of $0.1 \mathrm{M}$ hydrochloric acid, $2 \mathrm{ml}$ of $0.1 \%$ $\mathrm{KIO}_{4}$ and distilled water up to final volume of $25 \mathrm{ml}$ were added. After 2 minutes, the absorbance of each coloured solution at $509 \mathrm{~nm}$ against a similarly prepared reagent blank was measured. The linear relationship between absorbance and concentration of dapsone was observed up to $500 \mu \mathrm{g}$, as shown in Fig. (1). The molar absorptivity has been found to be $1.05 \times 10^{4} 1 . \mathrm{mol}^{-1} . \mathrm{cm}^{-1}$, and Sandell sensitivity index $0.0235 \mu \mathrm{g} . \mathrm{cm}^{-2}$. while the limit of detection (LOD) was found to be $0.1735 \mu \mathrm{g} / \mathrm{ml}$ and the limit of quantitation (LOQ) was found to be $0.5785 \mu \mathrm{g} / \mathrm{ml}$ (Valcared, 2000).

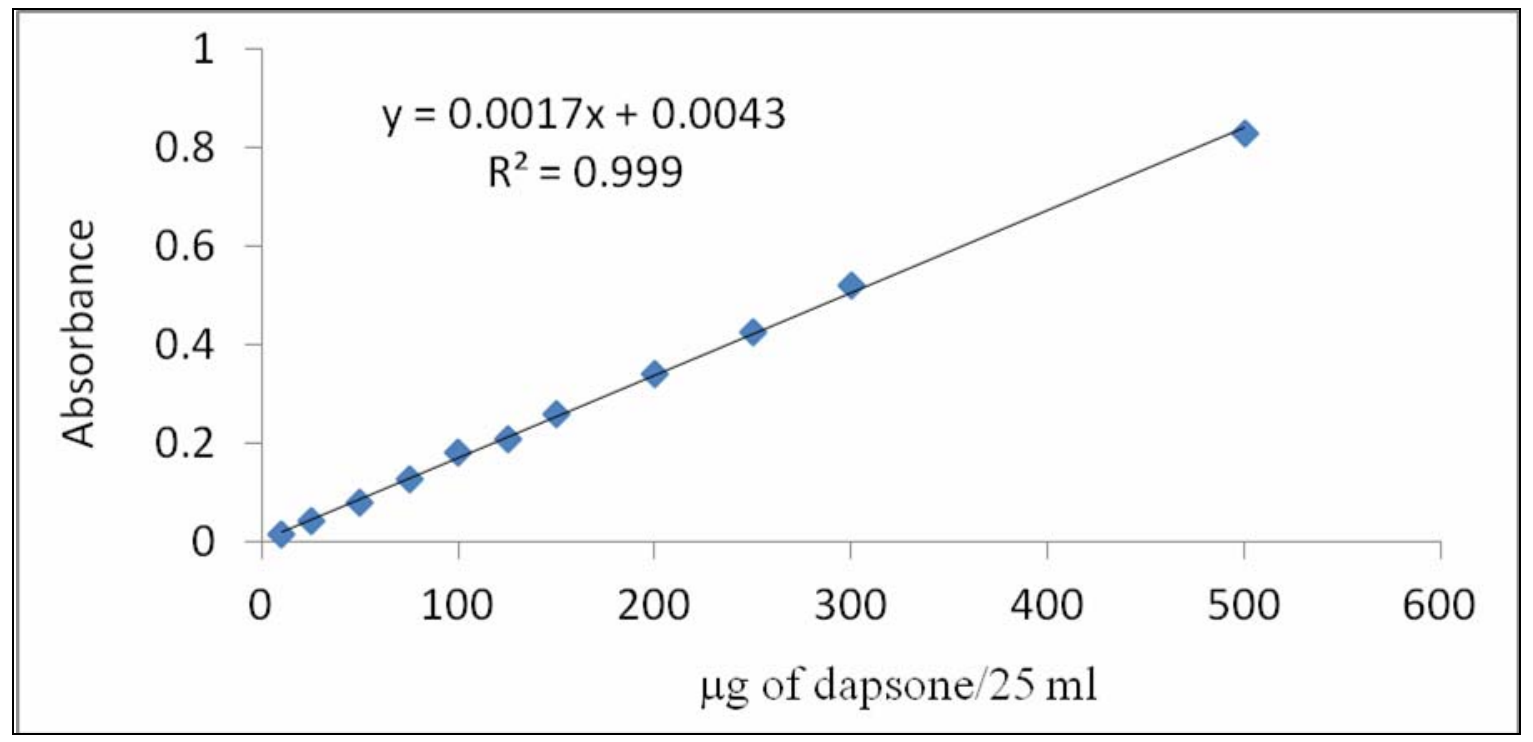

Fig. 1: Calibration graph for dapsone spectrophotometric determination.

\section{HPLC method:}

Dapsone standard solution was prepared in concentrations between $0.5-20 \mu \mathrm{g} / \mathrm{ml}$ in a mobile phase. The mobile phase consisted of (50:50) (v:v) water: acetonitrile isocratically eluted. Twenty $\mu \mathrm{L}$ of each standard solution was injected to $\mathrm{C}_{18}$ column, the mobile phase flow rate equal to $0.5 \mathrm{ml} / \mathrm{min}$., the peak area of dapsone was plotted as a function of dapsone concentration at ambient temperature. The peak of dapsone was followed at 6.7 $\min$. 


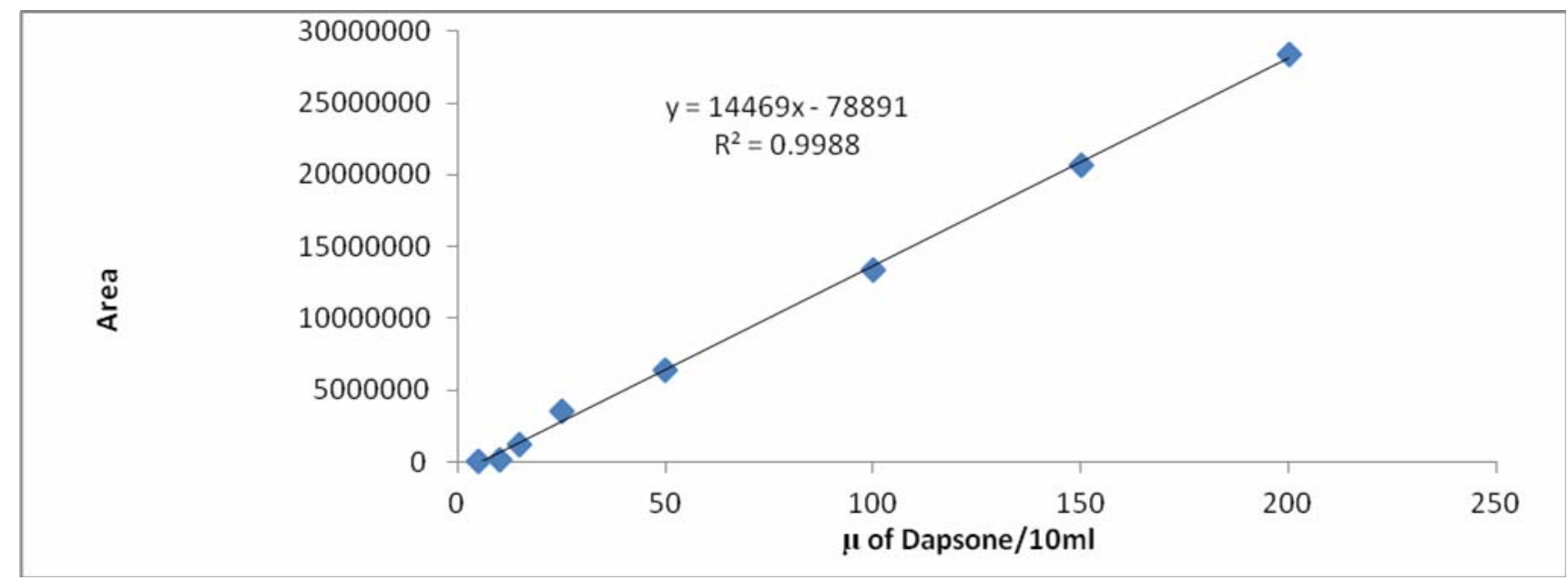

Fig. 2: Calibration graph of HPLC method.

A linear calibration graph is obtained between the area under the curve and the concentration over the range $0.5-20 \mu \mathrm{g} . \mathrm{ml}^{-1}$ of dapsone was obtained.

\section{Procedure for dosage form:}

For tablets, ten tablets (100 mg Dapsone / tablet) of the drug were weighed, powdered and mixed well. A portion equivalent to $0.01 \mathrm{~g}$ was weighed and dissolved in $50 \mathrm{ml}$ of distilled water, shaken well, filtered and diluted with water to $100 \mathrm{ml}$ in a volumetric flask. An aliquot of diluted drug solution was then treated as done in the recommended procedure.

\section{RESULTS AND DISCUSSION}

\section{Principle of the colour reaction:}

Dapsone reacts with pyrocatechol in the presence of potassium periodate in acidic medium:
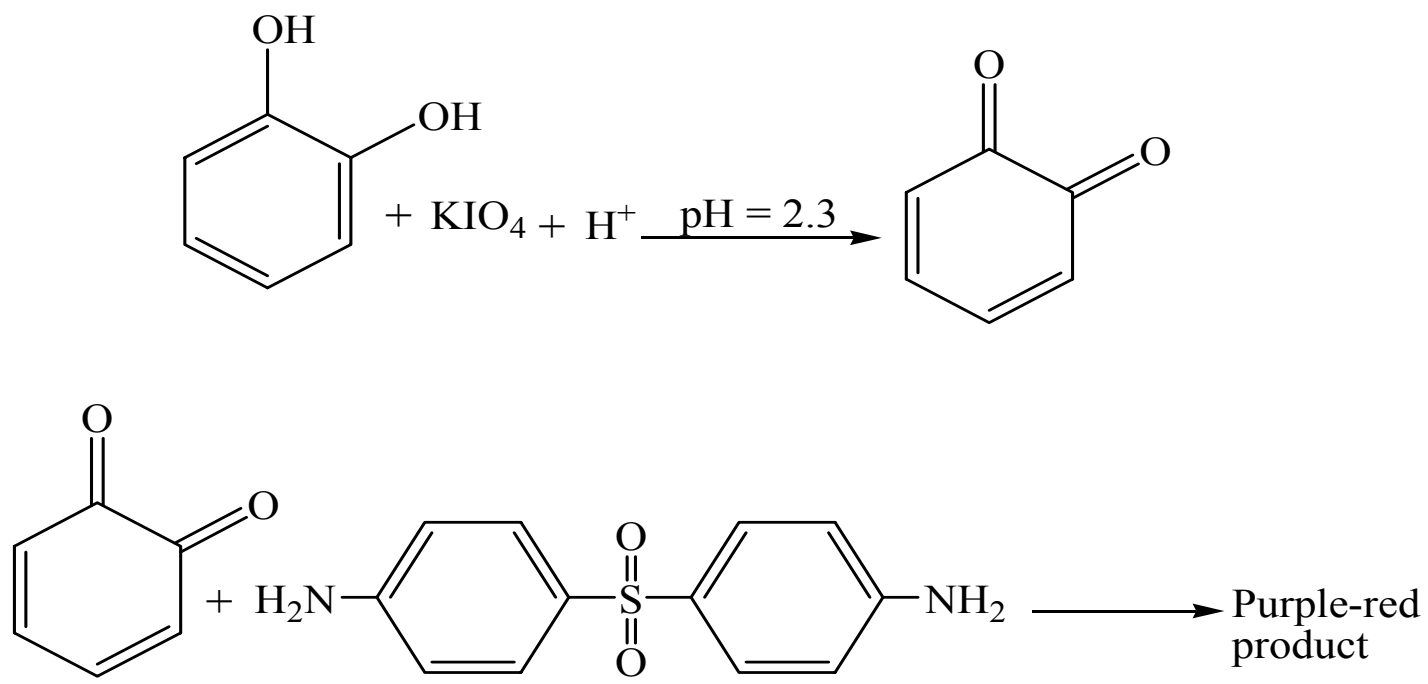

\section{Study of the optimum reaction conditions}

The various parameters which affect the colour intensity of the complex have been studied and the optimum conditions were selected. 


\section{Effect of oxidizing agents:}

The effect of some general oxidizing agents on the intensity of the coloured dapsone pyrocatechol dye was studied by adding $3 \mathrm{ml}$ of pyrocatechol $\left(2.7 \times 10^{-3} \mathrm{M}\right), 3 \mathrm{ml}$ of different oxidizing agents $(0.1 \%)$, potassium periodate, potassium dichromate, potassium chromate, potassium iodide, N-bromosuccinimide, N-chlorosuccinimide and ammonium ferric sulphate, $2 \mathrm{ml}\left(100 \mu \mathrm{g} . \mathrm{ml}^{-1}\right)$ of dapsone and $2 \mathrm{ml}(0.1 \mathrm{M})$ hydrochloric acid solution. The volumes were completed with distilled water to the mark in a $25-\mathrm{ml}$ volumetric flasks. The absorbance was measured at $515 \mathrm{~nm}$. From the experimental data, it can be stated that potassium periodate gave good results with a low blank absorbance value, which was selected for subsequent experiments.

\section{Effect of acids:}

Various acids (hydrochloric acid, nitric acid, sulphuric acid, phosphoric acid, acetic acid and formic acid) with different amounts had been investigated to examine their effect on the intensity of the coloured dye. The results revealed that the $1 \mathrm{ml}$ of $0.1 \mathrm{M}$ hydrochloric acid solution gave the best results.

\section{Effect of pH:}

The influence of $\mathrm{pH}$ on the colour intensity of the complex formed has been studied by transferring $3 \mathrm{ml}$ of $2.7 \times 10^{-3} \mathrm{M}$ solution of pyrocatechol reagent, $2 \mathrm{ml}$ of $0.1 \%$ potassium periodate solution, $200 \mu \mathrm{g}$ of dapsone and different volumes of $0.1 \mathrm{M} \mathrm{HCl}$ and $0.1 \mathrm{M} \mathrm{NaOH}$, separately. The volumes were then completed with distilled water to $25 \mathrm{ml}$ in volumetric flask. The absorbance were measured at $515 \mathrm{~nm}$ for each solution and the final $\mathrm{pH}$ was measured.

From the experimental data, the higher absorbance was observed to occur in acidic medium at pH 2.1 - 2.7. Further, colour formed is stable and contrasted. In basic medium, the coloured was different and the sensitivity had been lowered and a ccompanied by a weak contrast. So, the acidic medium had been selected for the subsequente experiments.

\section{Effect of dapsone amounts to the reagent amounts:}

To study this effect, different volumes of pyrocatechol $\left(2.7 \times 10^{-3} \mathrm{M}\right), 2 \mathrm{ml}$ of $0.1 \%$ potassium periodate, various amounts of dapsone $\left(10,25,50,75,100,125,150,200 \mu \mathrm{g} . \mathrm{ml}^{-1}\right)$ and $2 \mathrm{ml}$ of hydrochloric acid solution ( $0.1 \mathrm{M})$. The solutions were mixed and diluted with distilled water to the mark into a $25 \mathrm{ml}$ volumetric flask, and then the absorbance was measured at $515 \mathrm{~nm}$ against a reagent blank prepared in the same manner.

The results summarized that $1.5 \mathrm{ml}$ of $\left(2.7 \times 10^{-3} \mathrm{M}\right)$ pyrocatechol and $200 \mu \mathrm{g} \cdot \mathrm{ml}^{-1}$ of dapsone gave the best absorbance and the correlation coefficient is 0.998 which gave the maximum colour intensity. The optimum values are selected in all subsequent experiments.

\section{Effect of temperature:}

The effect of temperature on the colour intensity of the coloured product was studied. This was performed by placing into three $25-\mathrm{ml}$ calibrated flasks, the first one is allowed to stand for increasing time intervals at room temperature, the second at $0{ }^{\circ} \mathrm{C}$, and the third at $60{ }^{\circ} \mathrm{C}$ using water bath.

The results recommended that the absorbance of the colour purple-red was decreased when the reaction was carried out at $0{ }^{\circ} \mathrm{C}$ or $60^{\circ} \mathrm{C}$. Therefore, the reaction mixture should be carried out at room temperature. 


\section{Effect of delay time:}

The coloured product was developed rapidly after the addition of the oxidant and exhibited a maximum intensity at room temperature, different delay times was examined the data showed that the development time was 2 minutes which was allowed before measuring the samples.

\section{Effect of surfactants:}

The effect of the presence of surfactants on the colour intensity of dapson-catechol dye was examined, cetyl pyridinium chloride (CPC) and cetyltrimethyl ammonium bromide (CTAB) (cationic surfactant), sodium dodecyl chloride (SDS) (anionic surfactant) and Tween 80 (nonionic surfactant) were tested. The results reveal that the presence of surfactants have no beneficial effect at all. Therefore, it has been recommended to eliminate the use of surfactants in the subsequent experiments.

\section{Order of addition:}

From the different possible orders of addition of reagents, the order (Dapsone+Reagent $+\mathrm{HCl}+\mathrm{KIO}_{4}$ ) is selected for the subsequent experiments, otherwise a loss in colour intensity is observed.

\section{Effect of time:}

To determine the suitable time for absorbance measurement, the effect of time on the development and stability of the coloured complex was investigated under optimum conditions at the wavelength of maximum absorption at $509 \mathrm{~nm}$. Table (1) showed the result that the stability period of at least $60 \mathrm{~min}$ is sufficient for many measurements to be made.

Table 1: Effect of Time.

\begin{tabular}{|c|c|c|c|c|c|}
\hline \multirow{2}{*}{$\begin{array}{c}\text { Time } \\
(\mathbf{m i n})\end{array}$} & \multicolumn{5}{|c|}{ Absorbance / $\boldsymbol{\mu g}$ of dapsone present } \\
\cline { 2 - 6 } & 10 & 50 & 100 & 200 & 400 \\
\hline ADTTM $^{*}$ & 0.008 & 0.066 & 0.128 & 0.346 & 0.624 \\
\hline 5 & 0.006 & 0.066 & 0.128 & 0.346 & 0.626 \\
\hline 10 & 0.011 & 0.066 & 0.127 & 0.344 & 0.626 \\
\hline 15 & 0.010 & 0.067 & 0.126 & 0.344 & 0.624 \\
\hline 20 & 0.010 & 0.061 & 0.127 & 0.342 & 0.622 \\
\hline 25 & 0.010 & 0.063 & 0.126 & 0.342 & 0.622 \\
\hline 30 & 0.014 & 0.061 & 0.124 & 0.341 & 0.622 \\
\hline 35 & 0.014 & 0.061 & 0.124 & 0.342 & 0.620 \\
\hline 40 & 0.013 & 0.063 & 0.121 & 0.340 & 0.620 \\
\hline 45 & 0.007 & 0.059 & 0.118 & 0.340 & 0.620 \\
\hline 50 & 0.006 & 0.057 & 0.119 & 0.340 & 0.621 \\
\hline 55 & 0.004 & 0.052 & 0.115 & 0.340 & 0.619 \\
\hline 60 & 0.004 & 0.052 & 0.115 & 0.339 & 0.619 \\
\hline
\end{tabular}

*ADTTM : After dilution to the mark

\section{Final absorption spectra:}

When dapsone and pyrocatechole reagent solution are mixed in the presence of $\mathrm{KIO}_{4}$ in acidic media, an immediate purple-red coloured complexes are formed. Fig. (3) shows a single maximum absorption at $509 \mathrm{~nm}$, whereas the reagent blank gives a maximum absorption at $389 \mathrm{~nm}$. 


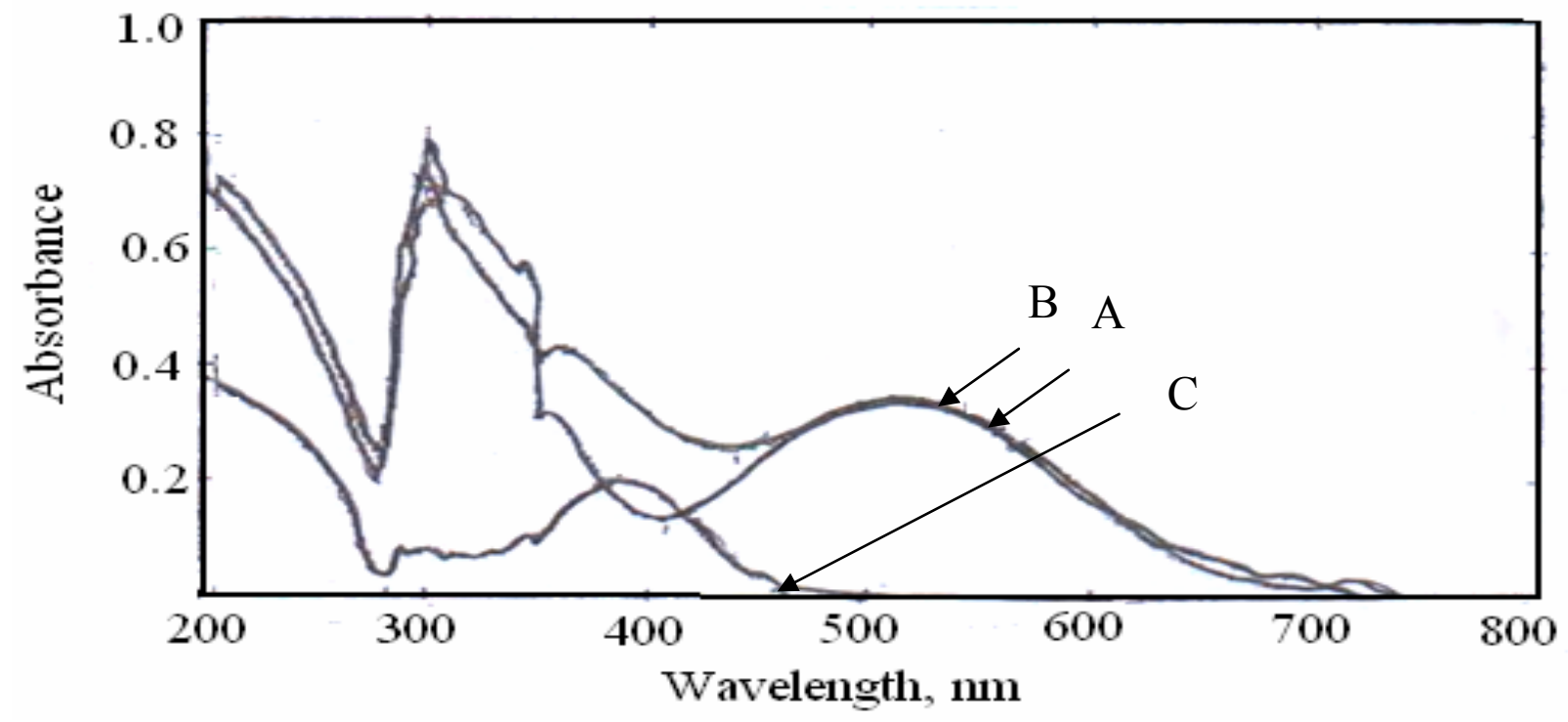

Fig. 3: Absorption spectra of $200 \mu \mathrm{g} / 25 \mathrm{ml}$ measured, (A) against blank, (B) against distilled water, $(C)$ blank against distilled water

The $509 \mathrm{~nm}$ wavelength of maximum absorption is still being adapted for subsequent experiments.

\section{Accuracy and precision:}

The accuracy and precision had been checked by determining dapsone at four different concentrations $(25,50,100,200) \mu \mathrm{g}$. The results showed that the recoveries were between (100 to101.1)\% and the relative standard deviations were ranged between \pm 2.60 to \pm 1.05 , indicating a satisfactory method.

\section{Nature of the dye:}

The composition of the intense purple-red dye has been established using Job's method of continuous variations. Fig.(4) has shown that the dapsone and pyrocatechol reagent combine in a 1:2 ratio.

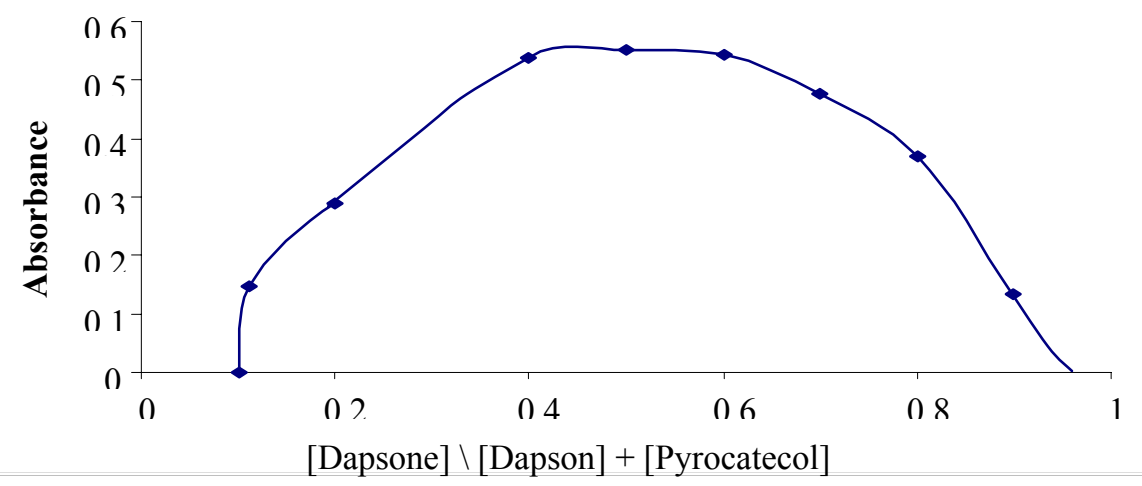

Fig. 4: Continuous variations plot for dapsone - pyrocatechol coloured product 
Therefore, the structure of the formed coloured product might be represented as follows:

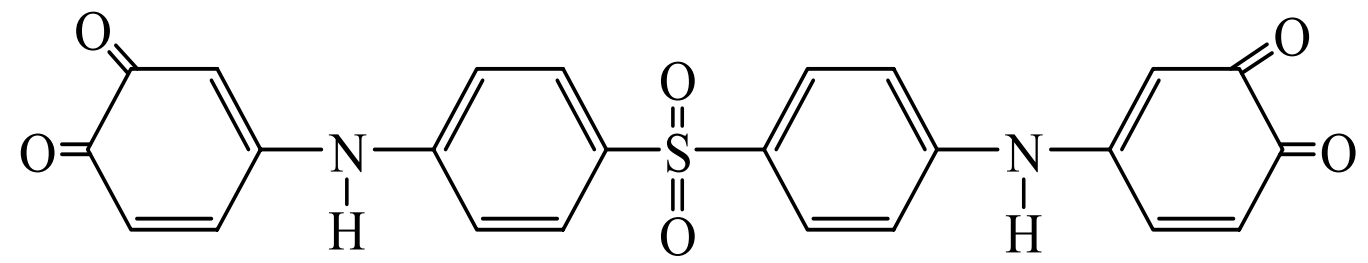

Purple-red product

\section{Effect of organic solvents:}

The spectral characteristics of the purple-red coloured product in various organic solvents are shown Table (2). Water is shown to be a good medium from the point of view of sensitivity and economy, therefore it has still been recommended for dilution.

Table 2: Spectrophotometric characterization of the coloured product in various Organic solvents.

\begin{tabular}{|c|c|c|}
\hline Solvent & $\boldsymbol{\lambda} \mathbf{m a x}, \mathbf{n m}$ & $\mathbf{\varepsilon}, \mathbf{l . m o l} \mathbf{~} \mathbf{~} \mathbf{. c m}^{\mathbf{- 1}}$ \\
\hline Acetic acid & 512 & $5.8 \times 10^{4}$ \\
\hline Acetone & 494 & $4.9 \times 10^{4}$ \\
\hline DMF & 478 & $4.6 \times 10^{4}$ \\
\hline Ethanol & 480 & $2.8 \times 10^{4}$ \\
\hline Formic acid & 546 & $4.7 \times 10^{4}$ \\
\hline Methanol & ---- & Turbid \\
\hline Propanol & 494 & $5.0 \times 10^{4}$ \\
\hline Pyridine & 560 & $2.5 \times 10^{4}$ \\
\hline Water & 510 & $6.3 \times 10^{4}$ \\
\hline
\end{tabular}

\section{Study of interferences:}

In order to assess the possible analytical application of the present proposed method, the effect of foreign compounds had been studied by carrying out the determination of $200 \mu \mathrm{g}$ of dapsone in the presence of different amounts $(50,100,200,400) \mu \mathrm{g}$ of each interferent using the recommended procedure.[Table (3)].

Experimental results showed that there was no interference from excipients for the examined method. 
Table 3: Effect of interferences.

\begin{tabular}{|l|l|l|l|l|}
\hline \multirow{2}{*}{ Interferences } & \multicolumn{4}{|l|}{$\begin{array}{l}\text { Recovery, \% of } 200 \\
\text { interference }\end{array}$} \\
\cline { 2 - 5 } & 50 & 100 & 200 & 400 \\
\hline Acacia & 97.4 & 100.3 & 95.9 & 95.9 \\
\hline Dextrose & 102.3 & 99.1 & 98.8 & 98.5 \\
\hline EDTA & 99.3 & 99.3 & 98.4 & 98 \\
\hline Glucose & 100.3 & 100.5 & 100.8 & 100.9 \\
\hline Glycerol & 98.6 & 99.3 & 99.3 & 99.7 \\
\hline Lactose & 98.1 & 97.3 & 100.3 & 100.8 \\
\hline Menthol & 100.5 & 100.3 & 100.3 & 100.2 \\
\hline Starch & 100.3 & 101.7 & 102.6 & 102.5 \\
\hline Sucrose & 101.7 & 101.4 & 100.5 & 100.2 \\
\hline
\end{tabular}

\section{Application of the method:}

The developed method had been applied to the determination of dapsone in pharmaceutical preparation (Tablet), the results are shown in Table (4).

Table 4: Determination of Dapsone in tablet.

\begin{tabular}{|l|l|l|l|l|}
\hline $\begin{array}{l}\text { pharmaceutical } \\
\text { preparation }\end{array}$ & $\begin{array}{l}\text { Certified } \\
\text { value }(\mathbf{m g}) \\
\text { tablets }\end{array}$ & $\begin{array}{l}\boldsymbol{\mu g} \text { dapsone } \\
\text { present } / \mathbf{2 5} \mathbf{~ m l}\end{array}$ & $\begin{array}{l}\boldsymbol{\mu g} \text { dapsone } \\
\text { found / 25 ml }\end{array}$ & Recovery*, (\%) \\
\hline \multirow{3}{*}{ Dapsone } & \multirow{2}{*}{100} & 50 & 51.7 & 103.4 \\
\cline { 3 - 5 } & 100 & 100.6 & 100.6 \\
\cline { 2 - 5 } & 200 & 201.2 & 100.6 \\
\cline { 2 - 5 } & 300 & 300 & 100 \\
\hline
\end{tabular}

- Average of five determinations.

For comparison, standard addition method (Skoog et al., 2000) was used for the determination of dapsone under investigation in order to prove that the proposed method is applied in the determination of dapsone without interferences [Table (5) and Fig.(5)].

Table 5: Determination of dapsone using standard addition method.

\begin{tabular}{|l|l|l|l|l|}
\hline $\begin{array}{l}\text { pharmaceutical } \\
\text { preparation }\end{array}$ & $\begin{array}{l}\text { Certified } \\
\text { value (mg) } \\
\text { tablets }\end{array}$ & $\begin{array}{l}\boldsymbol{\mu} \text { Mg dapsone } \\
\text { present / 25 } \\
\text { ml }\end{array}$ & $\begin{array}{l}\boldsymbol{\mu g} \text { dapsone } \\
\text { found / 25 ml }\end{array}$ & $\begin{array}{l}\text { Recovery*, } \\
(\mathbf{\%})\end{array}$ \\
\hline \multirow{2}{*}{ Dapsone } & \multirow{2}{*}{100} & 200 & 203.10 & 101.5 \\
\cline { 2 - 5 } & 300 & 301.06 & 100.3 \\
\hline
\end{tabular}

* Average of four determinations. 


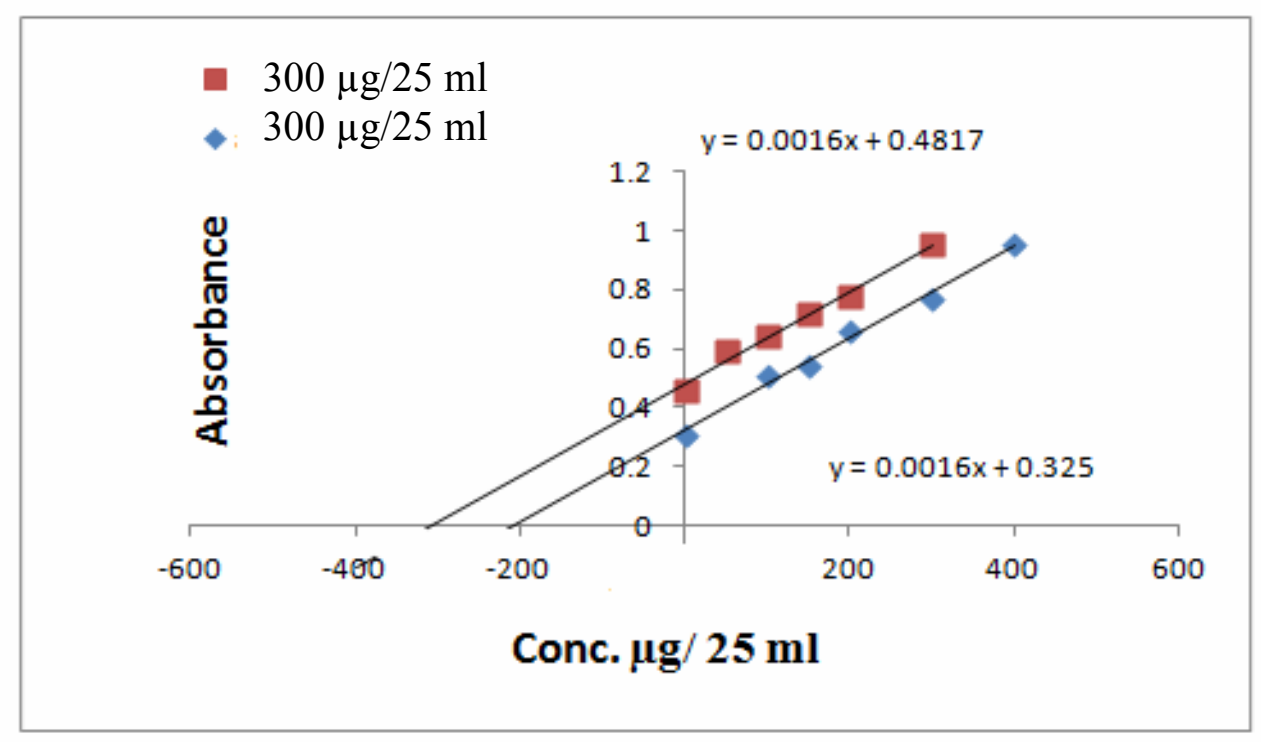

Fig. 5: Graph of standard addition method for the determination of dapsone in tablets.

The results in Table (5) and Fig. (5) indicating that the suggested method for the determination of dapsone can be used with satisfactory results.

Both the present and standard addition methods have been applied at the same time to F-test and t-test calculation and the value compared with the statistical tables for six degrees of freedom at 95\% confidence level. The results in Table (6) showed that there is no real difference between the two methods.

Table 6: The results of $F$ and t-test analysis

\begin{tabular}{|c|c|c|c|c|c|}
\hline \multirow[b]{2}{*}{ Drug } & \multirow{2}{*}{$\begin{array}{l}\text { Pharmaceutical } \\
\text { preparation }\end{array}$} & \multicolumn{2}{|c|}{ Recovery *\% } & \multirow[b]{2}{*}{ F-test } & \multirow[b]{2}{*}{ t-exp. } \\
\hline & & $\begin{array}{l}\text { Present } \\
\text { method }\end{array}$ & $\begin{array}{l}\text { Standard } \\
\text { addition }\end{array}$ & & \\
\hline Dapsone & Tablet & 100.5 & 101.5 & 9.217 & 0.69 \\
\hline
\end{tabular}

- Average of four determinations.

\section{Comparison of the method:}

Table 7 is showing a comparison between some analytical variable for the present method and those of the recent spectrophotometric methods. 
Table 7 : Comparison of the methods

\begin{tabular}{|l|l|l|l|l|}
\hline $\begin{array}{l}\text { Analytical } \\
\text { parameters }\end{array}$ & $\begin{array}{l}\text { Present } \\
\text { method }\end{array}$ & $\begin{array}{l}\text { Literature method } \\
\text { (Al-Abachi, 1995) }\end{array}$ & $\begin{array}{l}\text { Literature } \\
\text { method } \\
\text { (Al-Talib, 1997) }\end{array}$ & $\begin{array}{l}\text { Literature method } \\
\text { (Nagaraja, 2010) }\end{array}$ \\
\hline Reagent & Pyrocatechol & $\begin{array}{l}\text { Promethazine } \\
\text { hypochlorite }\end{array}$ & $\begin{array}{l}\text { 4-amino-N,N- } \\
\text { diethylaniline }\end{array}$ & $\begin{array}{l}\text { N,N-diethyl-p- } \\
\text { phenylenediamine } \\
\text { sulphate }\end{array}$ \\
\hline$\lambda$ max $(\mathrm{nm})$ & 509 & 604 & 551 & 550 \\
\hline Colour of dye & Purple-red & Bluish-green & Red-violet & Red \\
\hline Beer's law $(\mathrm{ppm})$ & $0.4-20$ & $0.2-4$ & $0.1-36$ & $1.5-12$ \\
\hline $\begin{array}{l}\text { Molar absorptivity } \\
\left(1 . \mathrm{mol}^{-1} . \mathrm{cm}^{-1}\right)\end{array}$ & $1.05 \times 10^{4}$ & $2.9 \times 10^{4}$ & $1.34 \times 10^{4}$ & $1.66 \times 10^{4}$ \\
\hline pH & 2.4 & 2.5 & 2.8 & - ----- \\
\hline Medium & Aqueous & Aqueous & Aqueous & Organic \\
\hline Temperature, $\mathrm{C}^{\circ}$ & R.T & R.T & R.T & $60 \pm 5$ \\
\hline Recovery, $\%$ & $100-101.1$ & $100.26-101.6$ & ----- & $99.5-99.9$ \\
\hline RSD, $(\%)$ & $1.05-2.60$ & $0.27-0.54$ & Less than $2 \%$ & $0.1-2.2$ \\
\hline LOD $(\mathrm{mg} / \mathrm{ml})$ & 0.0145 & ----- & ---- & 0.44 \\
\hline $\begin{array}{l}\text { Analytical } \\
\text { application }\end{array}$ & Tablets & Tablets & Tablets & $\begin{array}{l}\text { Pharmaceutical } \\
\text { dosage forms }\end{array}$ \\
\hline
\end{tabular}

\section{HPLC method}

\section{Selection of wavelength}

The absorption spectrum of $25 \mu \mathrm{g} \cdot \mathrm{ml}^{-1}$ of dapsone in 50:50 (v:v) water: acetonitrile has been taken, Fig. (6) shows that maximum absorbance of dapsone is at $297 \mathrm{~nm}$. Therefore, $297 \mathrm{~nm}$ has been used for UV-detection.

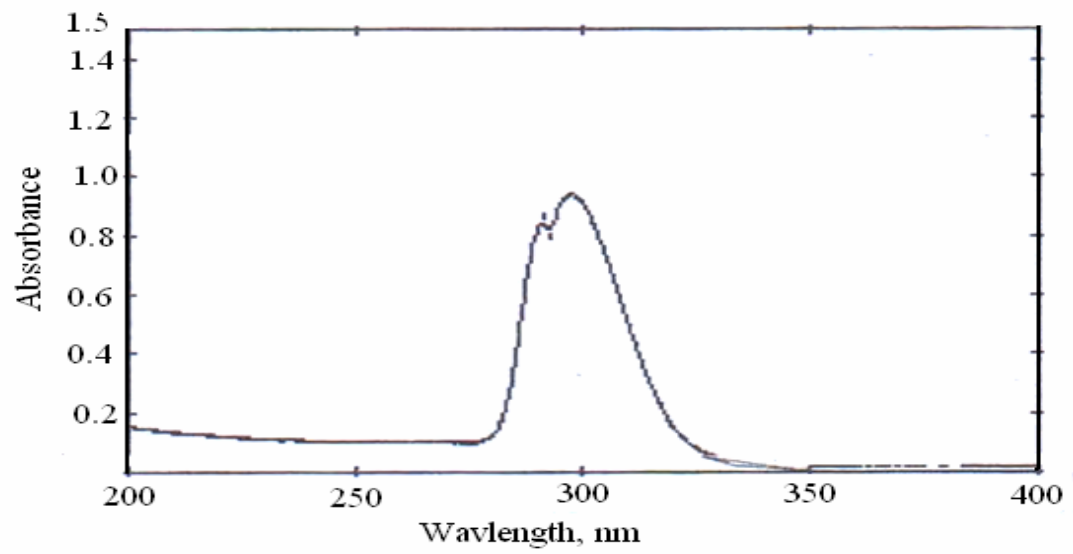

Fig. 6: Selection of wave length.

\section{Selection of mobile phase}

Different polar solvents with various compositions (used as a mobile phase) have been used to construct the optimum composition. The retention time and capacity factor have been followed in Table (8) and Fig. (7-1). 
Table 8: Selection of the mobile phase

\begin{tabular}{|l|l|l|}
\hline Mobile phase composition & $\begin{array}{l}\text { Retention } \\
\text { time, min. }\end{array}$ & Capacity factor, K \\
\hline $\begin{array}{l}\text { Water: methanol } \\
(60: 40)\end{array}$ & 5.36 & 1.329 \\
\hline $\begin{array}{l}\text { Water: acetonitrile } \\
(60: 40)\end{array}$ & 5.72 & 1.690 \\
\hline $\begin{array}{l}\text { Water: acetonitrile : methanol } \\
(75: 20: 5)\end{array}$ & 11.63 & 4.631 \\
\hline
\end{tabular}

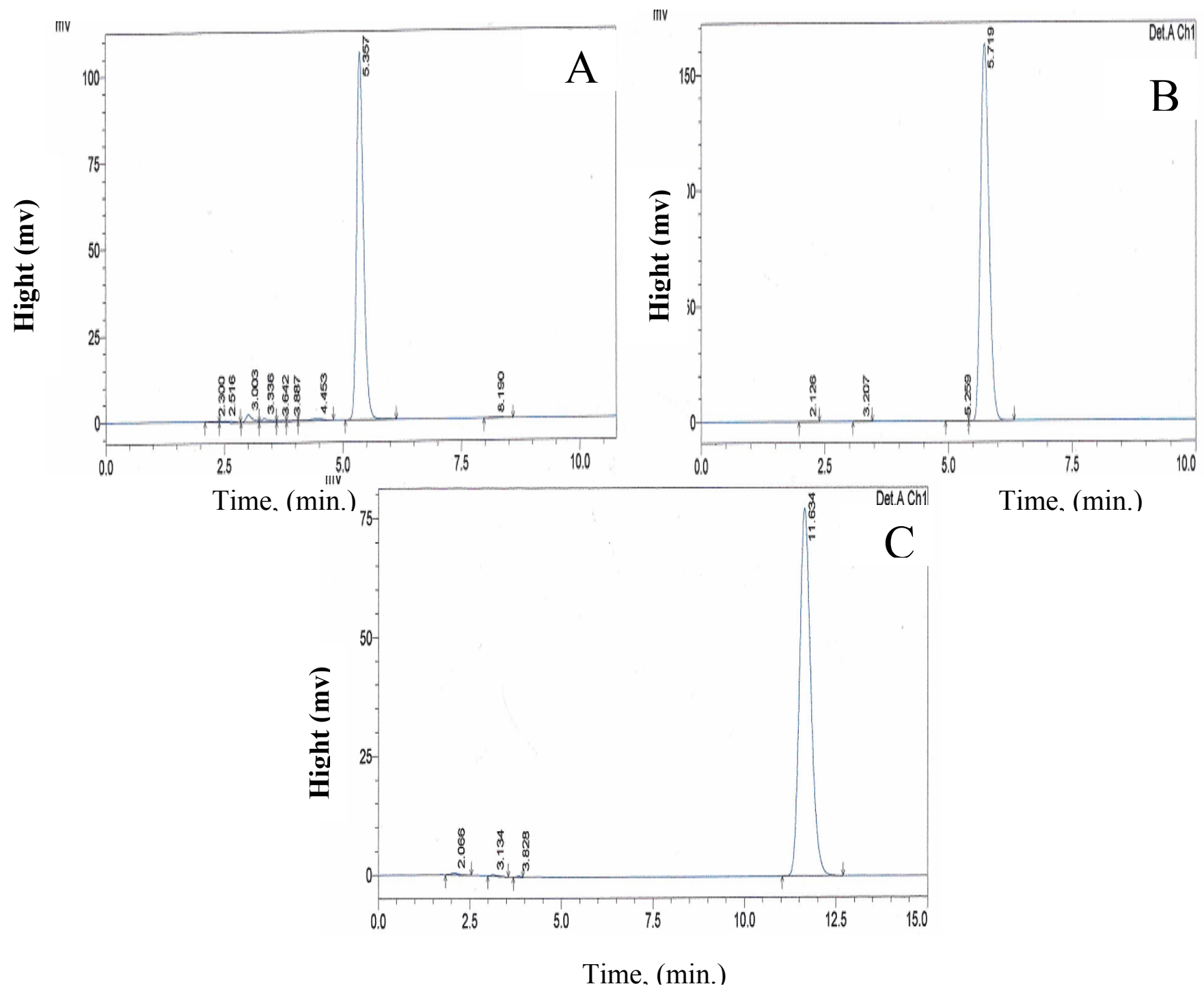

Fig. (7-I): Selection of mobile phase.

$$
\begin{aligned}
& \text { A }=\text { Water: Methanol (60:40) } \\
& \text { B }=\text { Water: Acetonitrile (60:40) } \\
& \text { C }=\text { Water: Acetonitrile: Methanol (73:20:5) }
\end{aligned}
$$


Fig. (7-I) shows that the case B is more useful because the resolution is better than the others, so that various volumes ratio of water: acetonitrile studied as mobile phase Fig.(7-II) shows that the graph is more useful because the resolution is the best and it is associated with higher sensitivity. Therefore, the condition reported in Fig.(7-II) $\mathrm{C}$ is recommended.
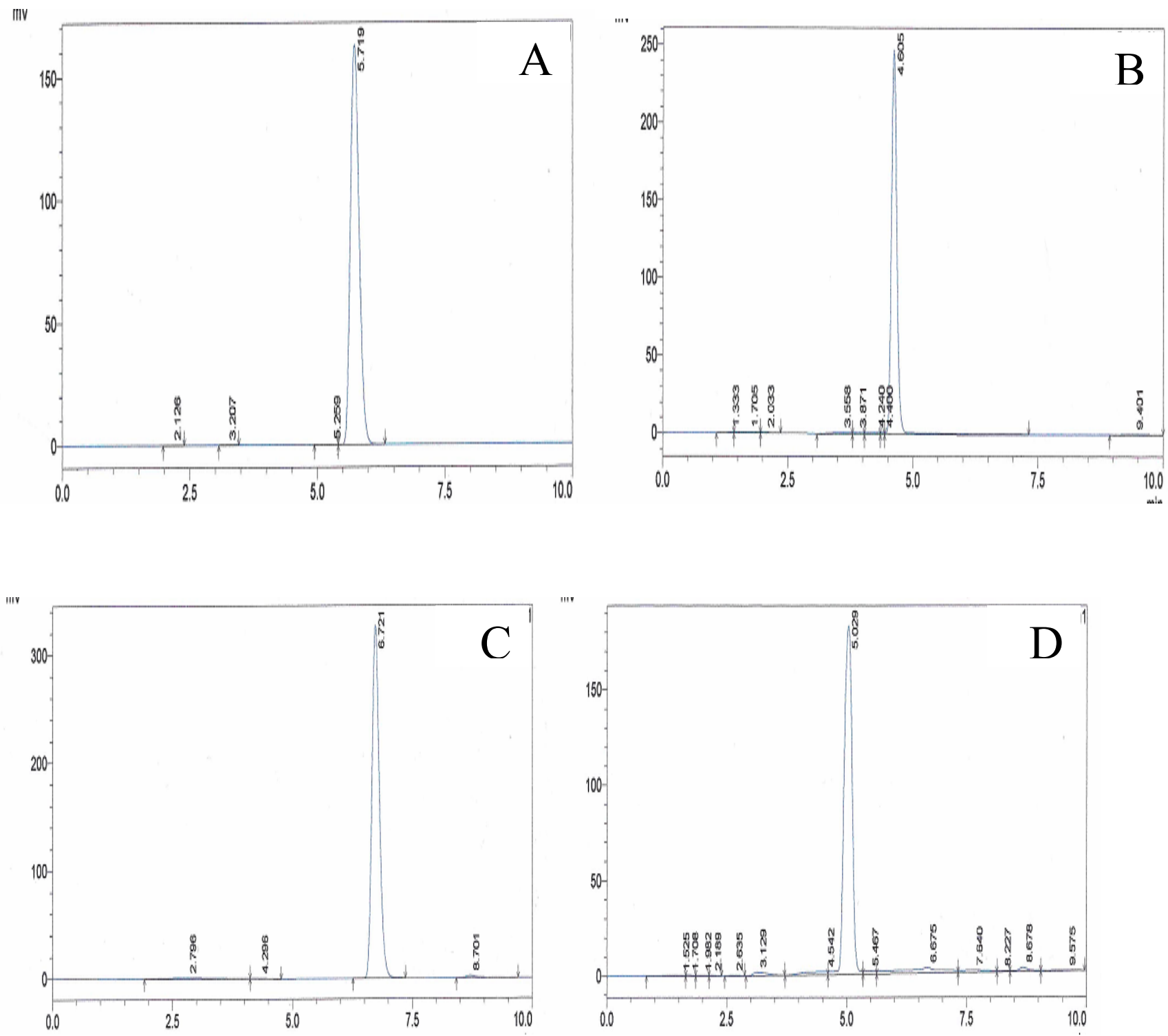

Fig. (7-II): Selection of volumes ratio of mobile phase.

$$
\begin{aligned}
\text { Water : Acetonitrile } \\
\mathbf{A}=\mathbf{( 6 0 : 4 0 )} \\
\mathbf{B}=\mathbf{( 7 0 : 3 0 )} \\
\mathbf{C}=\mathbf{( 5 0 : 5 0 )} \\
\mathbf{D}=\mathbf{( 4 0 : 6 0 )}
\end{aligned}
$$




\section{Selection of flow rate:}

A flow rate $(0.5-1.2) \mathrm{ml} . \mathrm{min}^{-1}$ as a flow rate has been studied, $0.5 \mathrm{ml} . \mathrm{min}^{-1}$ gives the optimum capacity factor Table (7) with clear chromatography and good sharpness Fig. (8).

\section{Table 9: Selection of floe rate}

\begin{tabular}{|l|l|l|l|}
\hline No. & $\begin{array}{l}\text { Flow rate } \\
(\mathbf{m l} / \mathbf{m i n} .)\end{array}$ & $\begin{array}{l}\text { Retention time } \\
(\mathbf{m i n} .)\end{array}$ & Capacity factor K \\
\hline I & 0.5 & 6.721 & 1.40 \\
\hline II & 0.7 & 5.698 & 1.68 \\
\hline III & 0.9 & 4.592 & 1.77 \\
\hline IV & 1.0 & 3.999 & 1.52 \\
\hline V & 1.2 & 3.365 & 1.63 \\
\hline
\end{tabular}

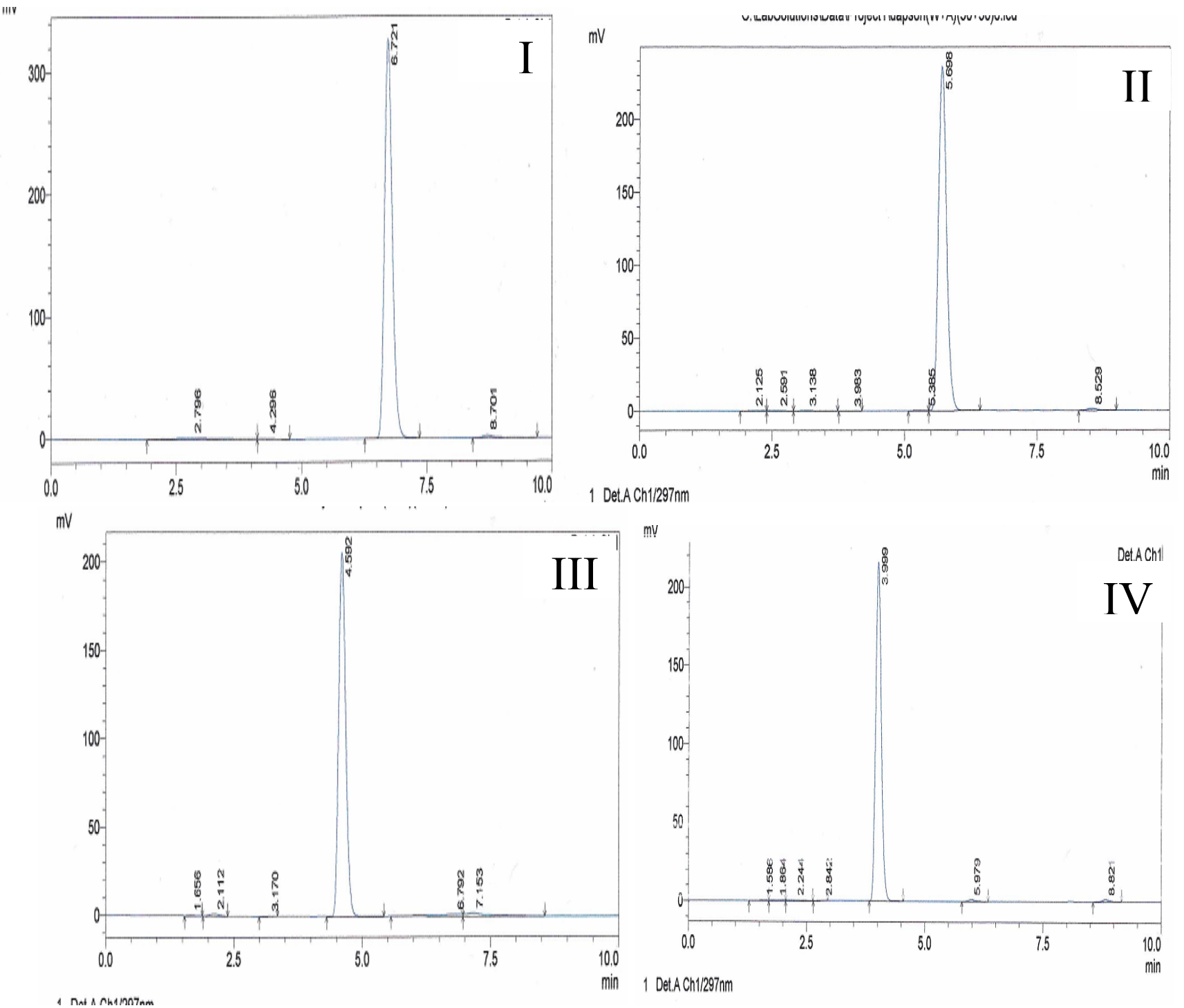




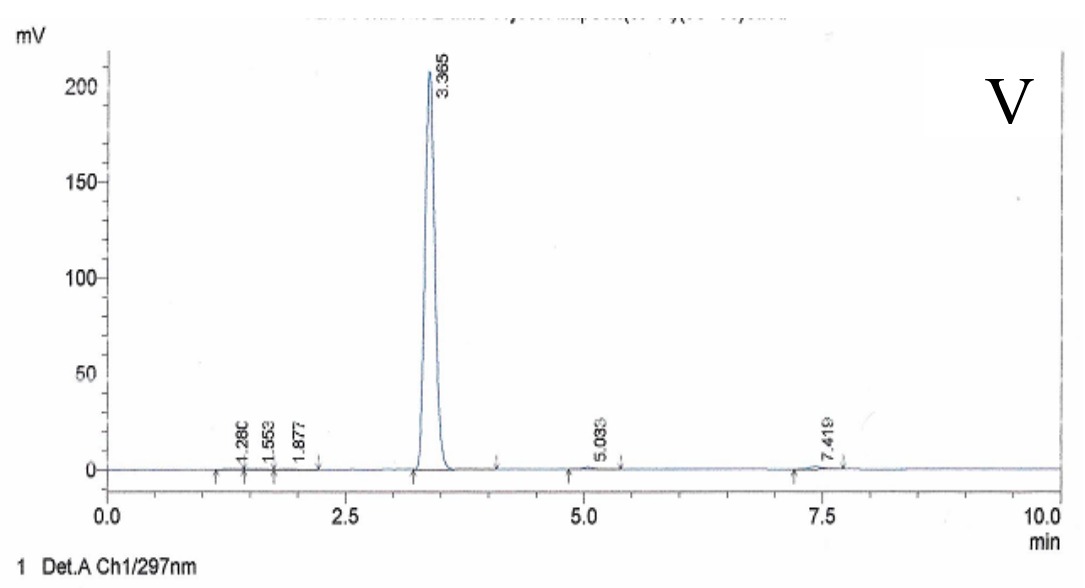

Fig. 8: Selection of flow rate

\section{Accuracy and precision}

To study the accuracy and precision of the calibration graph, dapsone was determined at three different concentrations and the results are shown in Table (10), which indicate a good accuracy and precision.

Table 10: Accuracy and precision.

\begin{tabular}{|c|c|c|}
\hline $\begin{array}{c}\text { Amount of dapsone } \boldsymbol{\mu g}, \\
\text { taken }\end{array}$ & $\begin{array}{c}\text { Relative } \\
\text { error, \%* }\end{array}$ & $\begin{array}{c}\text { Relative standard } \\
\text { deviation, } \mathbf{\%}^{*}\end{array}$ \\
\hline 10 & 0.3 & \pm 0.83 \\
\hline 25 & 0.0 & \pm 0.53 \\
\hline 50 & 1.1 & \pm 1.3 \\
\hline
\end{tabular}

* Average of three determinations.

\section{CONCLUSIONS}

The suggested methods for the determination of dapsone are sensitive and temperature independent, applicable without resorting to an extraction step.

\section{ACKNOWLEDGMENT}

The author expresses her sincere thanks to Prof. Dr. W. A. Bashir, Chemistry Department, College of Science, Mosul University for his advices.

\section{REFERENCES}

Al-Abachi, M.Q.; AL-Najafi, S.; Shihbaz, N.A. (1995). Spectrophotometric determination of dapsone via oxidative coupling with promethazine and hydrochlorite. J. Edu. Sci., 24, 28-34.

Al-Abachi, R.Y.(1997). Spectrophotometric micro determination of dapsone via oxidative coupling with 4-amino-N.N-diethylaniline and dichromate. J. Edu. Sci, 27, 25-35.

Al-Ghabsha, T.S.; Ahmed, R.A. ; Mahmood, H. Sh. ( 2004). Spectrophotometric assay of Some drugs in their pharmaceutical preparations with stability study. J. Edu. Sci., 16, 31-41. 
Al-Ghabsha, T.S.; Ahmed, R.A. ; Mahmood, H. Sh. (2004). Spectrophotometric study of Some drugs using 2,3- dichloro-5,6-dicyano-p-benzoquinon (DDQ). J. Edu. Sci., 16, 42-54.

Al-Kadi, H.O. (2007). Anti malaria drug toxicity: a review, Chemotherapy. 53(6), 385-391.

Al-Ramadani, S. T. (2007). Development of spectrophotometric method for the determination of thymol, dapsone and tetracycline using diazotization coupling reaction. M.Sc. Thesis, Dept. of Chemistry, College of Education, University of Mosul, pp. 48-71.

Al-Talib, S. M. (1997). Spectrophotometric determination of dapsone in some pharmaceutical preparations. J. Edu. Sci., 26, 52-62.

British Pharmacopoeia on CD-ROM, (2009).Volume III, System Simulation 1td, Stationary Office London.

Croft, A. M. (2007). "Malaria: Prevention in Travelers, Clinical Evidence, Medical Headquarters". 5th Division, Shrewsbury, London, 0903 p.

Daood, L.T. (2008). Spectrophotometric determination of dapsone using phloroglucinol as a coupling reagent. Raf. J. Sci., 19 (3), 24-37.

Ferry, C.W.; Buck, J.S.; Batltzly, R., (1964). Method of preparation 4,4̀-diaminodiphenyl sulphone. Organic Synthesis, 3, 239-241.

Hadjigeorgiou, M.; Papuchruysostomou, Ch.; Theodoru, Z.; Kanari, P.; Constantinous, S. (2009). Determination of dapsone in meat and milk by liquid chromatogrophy tandem mass spectrometry. Anal. Chem. Acta. 637(1-2), 220-224.

Kwaddijk, S. ; Torano, J. S. (2002). High-performance liquid chromatographic method with ultraviolet detection for the determination of dapsone and its hydroxylated metabolite in human plasma, Biomed. Chromatogr., 16, 203-208.

Luan Chen, Y.U.; Tunga, H.; Tiang, X.; Naidong, W. (2003). Simultaneous determination of theophylline, tolbutamide, mephenytion, debrisoquin and dapsone in human plasma using high-speed gradient liquid chromatography. J. Sep. Sci, 26,15091519.

Mahmood, H.S. ( 2000). Analytical application of charge transfer complex to the assay and stability study of some drugs in pharmaceutical preparation, Ph.D. Thesis, Dept. of Chemistry, College of Education, University of Mosul, pp. 22-51.

Moffat, A.C.; Osselton, MD.; Widdop, B. (2005). "Clarke's Analysis of Drugs and Poisons". 3rd ed., Publication division of the Royal Pharmaceutical Society of great British, London, (Internet).

Mohammed, Sh. H.; AL-Najafi, S.I.; AL-Abachi, M.Q. (1994). Spectrophotometric micro determination of dapsone in some pharmaceutical preparation. J. Edu. Sci., 16, 5-17.

Moraes, N.V.; Mello, M. H.; Souza, A. M.; sampaio, S.V.; Queiroz, R. H. C. (2008). Potentiation of dapson induced methemoglobinemia in rats. Rev. Bras. Cienc. Farm., 44, 97-104.

Nagaraja, P.; Shivaswamy, M. ; Kumar, M. (2001). Highly sensitive N-(1-Naphthyl) ethylene diamine method for the spectrophotometric determination of trace amount of nitrite in various water samples. Intern. J. Environ. Anal. Chem., 80(1), 39-48. 
Nagaraja, P.; Yathirajan, H.S.; Suintha, K.R. ; Vasantha, R. A. (2002). Novel methods for the rapid spectrophotometric determination of dapsone. Anal. Letters., 35, 15311540.

Nagaraja, P.; Yathirajan, H.S.; Raju, C.R.; Vasantha, R.A.; Nagendra, P.; Hemantha Kumar, MS. (2003). 3-Aminophenol as a novel coupling agent for the spectrophotometric determination of sulphonamide derivatives. IL Farmaco., 58,1295-1300.

Nagaraja, P.; Shrestha, A.K.; Shivakumar, A. ; Gowda, A. K. (2010). Use of N,N-diethyl-pphenylene diamine sulphate for the spectrophotometric determination of some phenolic and amine drugs. Acta Pharm. 60, 217-227.

Omran, A. A. (2005). Individual and simultaneous spectrophotometric determination of dapsone and metoclopramide $\mathrm{HCl}$ in pharmaceutical dosage forms and synthetic binary mixtures. Chem. Pharm. Bull. (Tokyo), 53, 1498-1501.

Queiroz, R.H.C.; Dreossi, S.A.C. ; Carvalho, D. (1997). A rapid, specific and sensitive method for the determination of acetylation phenotype using dapsone. J. Analytical Toxicology, 21, 203-207.

Revanasiddappa, H.D.; Manju, B. (2001). A spectrophotometric method for the determination of metoclopramide $\mathrm{HCl}$ and dapsone. J. Pharm. Biomed. Anal., 25, 631-637.

Sailourglenisson, F.; Chene, G.; Salmi, L.R.; Hafner, R.; Salamon, R. (2000). Effect of dapsone on survival in HIV infected patient: ameta-analysis of finished trials. Rev. Epidemiol Santepublique, 48,17-30.

Shirazi, F.H.; Bahrami, G.; Stewart, D.S.; Tomiak, E.; Delovnce, F.; Noel, D.; Goel, R. (2001). Liquid chromatographic method for determination of etoposide (VP-16) in human plasma. J. Pharm. Biomed. Anal., 25, 187-192.

Skoog, A.D.; West, M.D.; Holler, F.J. ; Grouch , R.S. (2000). "Analytical Chemistry". 7th ed., Saunders College Publishing, New York, 601 p.

Valcarcel, M. (2000). "Principle of Analytical Chemistry Spring-Verlag". Berlin, 68 p.

Wang, H.Y.; Xu, L.X.; Xiao, Y.; Han, J. ( 2004). Spectrophotometric determination of dapsone in pharmaceutical products using sodium 1,2-naphthoquinone-4-sulponic as the chromogenic reagent. Spectrochem. Acta. A Mol. Biomol. Spectrosc., 60, 2933-2939. 